\title{
PHOTOVOLTAIC MODULE RECYCLING: THERMAL TREATMENT TO DEGRADE POLYMERS AND CONCENTRATE VALUABLE METALS
}

\author{
Priscila Silva Silveira Camargo ${ }^{1, *}$, Andrey da Silva Domingues ${ }^{1}$, João Pedro Guê Palomero ${ }^{1}$, \\ Angela Cristina Kasper ${ }^{1}$, Pablo Ribeiro Dias ${ }^{2}$ and Hugo Marcelo Veit ${ }^{1}$ \\ ${ }^{1}$ Department of Materials Engineering, Federal University of Rio Grande do Sul (UFRGS), Av. Bento Gonçalves, 9500, 91509-900, Porto \\ Alegre, RS, Brazil \\ ${ }^{2}$ School of Photovoltaics and Renewable Energy Engineering, University of New South Wales, UNSW, Sydney, NSW 2052, Australia
}

Article Info:
Received:
1 March 2021
Revised:
1 July 2021
Accepted:
26 July 2021
Available online:
xxxxxxxxxxxxxx
Keywords:
WEEE Recycling
Crystalline silicon photovoltaic
module
Thermal Treatment
Valuable Metals
Silver
Polymers

\section{INTRODUCTION}

\subsection{Solar Photovoltaic Energy}

In 2019, solar photovoltaic (PV) energy accounted for $22.9 \%$ of the global renewable energy market, staying behind hydro (44.7\%) and wind (23.4\%) energy, in terms of installed capacity (IRENA, 2021a). PV installed capacity has grown at unprecedented rates since the early 2000s in worldwide (Weckend et al., 2016) as it went from 22,817 MW in 2009 to 578,553 MW in 2019 (IRENA, 2021b). The energy from PV sources is a competitive technological alternative to other traditional energy sources since it is inexhaustible on the human time scale and is also more sustainable (Pinho \& Galdino, 2014; Tao \& Yu, 2015). In Germany, for example, the consumption of 47.5 TWh of PV energy avoided about 29 million tons of carbon dioxide emissions in 2019 (ISE, 2020).

\section{2 c-Si Photovoltaic Module Components}

Crystalline silicon (c-Si) is the oldest technology (first generation) used in modules from PV panels. Currently, this technology represents $95.4 \%$ of the solar panel market (ISE, 2020). Crystalline silicon PV modules are composed of several materials, such as high-transparency tempered glass, layers from ethyl vinyl acetate (EVA), crystalline silicon PV cells, copper and silver metal contacts, antireflection and passivation layers, a polymer backsheet and an aluminum frame. The backsheet is composed of a combination of polymers, that can contain polyvinyl fluoride (PVF or Tedlar $\left.{ }^{\circledR}\right)$, polyethylene terephthalate (PET), among others (Dias et al., 2017; Huang et al., 2017; Weckend et al., 2016).

Ultra-pure silicon (doped with boron, phosphorus, and aluminum) is used in c-Si PV cells. This material absorbs solar radiation and converts it into electrical current (De- 
Bergalis, 2004; Pinho \& Galdino, 2014; Strachala et al., 2017). A silver-aluminum paste is printed, in a grid pattern, on the front and back of the cell in order to form an electric field. The conductive copper ribbons are soldered (with lead and tin solder) along surfaces from PV cells (Huang et al., 2017).

\subsection{Photovoltaic Waste}

PV modules have a useful life estimated of about 25 30 years (Paiano, 2015). However, an increasing number of modules will reach the end of their lifespan before that time due to the damage during installation or storms, component failures, or economic incentives to replace older modules by new modules with higher efficiency (Tao et al., 2020).

Projections from International Renewable Energy Agency (IRENA) indicated that the global generation of PV waste could reach 8 million tons in 2030 and approach 80 million tons in 2050, considering an early loss scenario (Weckend et al., 2016). Considering a regular loss scenario, where only End-of-Life (EoL) panels are replaced, the projections are 1.7 million tons for 2030 and 60 million tons for 2050 .

In Europe, EoL PV panels started to be considered as "Waste of Electrical and Electronic Equipment" (WEEE) by the European WEEE Directive 2012/19/EU. Moreover, a reverse logistics system has been imposed on suppliers, manufacturers, importers and resellers of PV modules that are obliged to collect and recycle EoL PV modules (Padoan et al., 2019; Weckend et al., 2016).

\subsection{Environmental Risk}

Typically, more than $90 \%$ of PV modules mass is composed by glass, polymers and aluminum, which can be classified as non-hazardous waste. However, there are components in smaller proportion that require more attention such as silver, tin, lead and others metals in crystalline silicon panels. Furthermore, cadmium and arsenic - hazardous metals - are present in some thin film technologies (Weckend et al., 2016). These hazardous elements can cause environmental and public health problems in case of incorrect disposal (Aryan et al., 2018; Fthenakis, 2000).

According to BiolS report (2011), a particular concern is the large amount of lead in $\mathrm{C}-\mathrm{Si}$, approximately $12.67 \mathrm{~g}$ in a panel with about $22 \mathrm{~kg}$. Biols report (2011) informed that a c-Si module at its End-of-Life, disposed of in the environment, when leached by the rain, can release between $13 \%$ and $90 \%$ of the amount of lead found. Tammaro et al. (2016) performed leaching tests on crushed and broken samples of different PV technologies, with sizes between 0.5 and $3 \mathrm{~cm}$. Moreover, they investigated 18 releasable metals by chemical and ecotoxicological analysis. Some hazardous metals such as lead, chromium, nickel, tin and cadmium exceeded the legal limits of European and Italian laws for drinking water, soil discharge and inert disposal in landfills. By ecotoxicological evaluation, adverse effects were indicated mainly due to the occurrence of lead, tin and cadmium. In the same work, high amounts of lead (30 t) and cadmium (2.9 t) releasable from c-Si and thin film panels, respectively, were also predicted for 2050 .

Nain \& Kumar (2020) analyzed the release of metals from broken and unbroken solar panels that were exposed

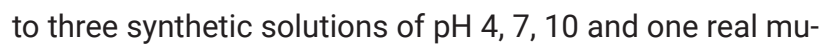
nicipal solid waste (MSW) landfill leachate for one year. The results suggested that encapsulant degradation plays a critical role and has a positive correlation with metal dissolution. They also indicated that the mass of exposed modules per volume of water increases the probability of leached metals exceeding standard limits. Nain \& Kumar (2020) reported that the increase in leaching contamination after one year of disposal of polycrystalline silicon modules was $54.19 \%$.

Furthermore, Nain \& Kumar (2020) observed that the leaching of metals in stormwater solutions was minimal, except for a few metals. For the initial months after disposal, the PV cells and films maintain their integrity because of encapsulation. So, disposal of EoL solar PVs in MSW landfills could result in less leaching from semiconductor layers. Therefore, they concluded that aggressive short-term standard waste characterization tests, such as Whole Effluent Toxicity Methods (WET/EPA) and Toxicity Characterization Leaching Procedure (TCLP/EPA), could poorly represent the release of metals from encapsulated materials in landfill leachate. They reported that the results obtained do not indicate that the disposal of PV in landfills is environmentally safe, but that there is a need for further investigations on different aspects, such as the effect of microbial activity, temperature variations, and composition of MSW waste on metal solubilization from PVs.

There is also concern about the release of poly/brominated flame retardants (Padoan et al., 2019), ozone-depleting chemicals such as Chlorofluorocarbons (CFCs). PV modules composition also contain fluoropolymers, such as Polyvinyl Fluoride (PVF) or Polyvinylidene Fluoride (PVDF), especially in the backsheet. These components can be harmful to both human health and the environment (Mulvaney, 2014; Yi et al., 2014). The burning of these fluoropolymers is a source of persistent compounds such as carbon fluorides, fluoroacids, dioxins, and furans (Aryan et al., 2018). Burning PVF generates $\mathrm{HF}$ at $350^{\circ} \mathrm{C}$ and benzene at $450^{\circ} \mathrm{C}$ (Huber et al., 2009).

\subsection{Economic Potential}

On the other hand, the disposal of PV modules in landfills is a wastage of valuable raw materials (such as silver, silicon, copper, gallium, indium, germanium, and tellurium) and conventional materials, such as aluminum and glass (Aryan et al., 2018; BiolS, 2011; Strachala et al., 2017).

In addition, this waste can represent opportunities in developing or transition economies, where waste collection and recycling services are often dominated by informal sectors (Weckend et al., 2016). Some of the materials recovered from Si modules can be sold directly on the commodities market. The largest amount of recovered materials are glass fragments (which must be free of Si cells) and Cu ribbons for reuse in the solar industry (Tao et al., 2020).

Preliminary estimates suggest that technically recoverable raw materials from $\mathrm{PV}$ panels could cumulatively yield a value of up to USD 450 million (in 2016 terms) by 2030 . This is equivalent to the amount of raw material currently required to produce approximately 60 million new panels or $18 \mathrm{GW}$ of power generation capacity. By 2050 , the re- 
coverable value could cumulatively exceed USD 15 billion, equivalent to 2 billion panels or $630 \mathrm{GW}$ (Kadro \& Hagfeldt, 2017; Weckend et al., 2016).

According to Tao et al. (2020), silver represented 35.2\% of the economic value obtained from recovering materials from a module, considering the price of USD 574.23/kg (Silver Price, 2019). In addition, copper represented $5.2 \%$ of the total economic value, considering the price of USD 5.0/ kg (Rockaway Recycling, 2019). On February 26th 2021, the silver price was USD $857.73 / \mathrm{kg}$ (Silver Price, 2021) and the copper price was USD 9.17/kg (Insider, 2021).

Huang et al. (2017) estimated the costs of a recycling process for the valuable materials derived from silicon PV modules. The authors affirm that revenue earned is enough to cover the recycling cost and maintain a profitable recycling business without any government support. However, Deng et al. (2019) concluded that glass recycling is economically viable only in countries where landfill rates are high or module landfilling is prohibited. In addition, mechanical processing and thermal recycling need to have their costs reduced by at least $30 \%$ to become economically viable. According to the authors, the application of large-scale recycling requires governments to act in reduction costs and regulation, manufacturers include recycling in design, and that recyclers search methods for silver and Si wafer recovery at lower processing costs. The study recommend that governments, manufacturers and recyclers work collaboratively to build a recycling network. In another paper, authors concluded that the circular use of high-purity silicon and intact silicon wafers from EoL PV modules can be economically feasible with a reduction of $20 \%$ in manufacturing cost in the second-life modules, despite some efficiency reductions (Deng et al., 2020).

\subsection{PV Modules Recycling Methods}

Currently, silver is the metal of greatest interest in the recycling process c-Si panel (Dias et al., 2016; Tao \& Yu, 2015) because it is a precious metal and its recovery adds economic value to the recycling of PV modules (Chancerel et al., 2009; Padoan et al., 2019). In the hydrometallurgical process, nitric acid is often applied to separate silver from PV cells. In this case, the purified crystalline silicon (solid phase) can be filtered, whereas the soluble silver in the leachate can be recovered from the residual acid by electrolysis or precipitation (Dias et al., 2016; Klugmann-Radziemska et al., 2010; Klugmann-Radziemska \& Ostrowski, 2010; Kuczyńska-Łażewska et al., 2018; Latunussa et al., 2016; Shin et al., 2017).

Dias et al. (2018) separated waste of silicon-based PV modules using an electrostatic separator after mechanical milling. Granata et al. (2014) investigated the recycling of polycrystalline silicon, amorphous silicon and CdTe PV panels by two alternative sequences of physical operations: two-blade crusher rotors followed by thermal treatment and two blade crusher rotors followed by hammer crushing. The best option was the treatment route that involved (1) crushing by two-blade rotor crusher; (2) hammer crushing; (3) thermal treatment at $650^{\circ} \mathrm{C}$ of fractions larger than $1 \mathrm{~mm}$; and (4) screening through a $0.08 \mathrm{~mm}$ sieve. By these operations, around $85 \%$ of the total weight of the panels was recovered as glass from the fractions larger than $0.08 \mathrm{~mm}$. Concerning the thermal treatment, they obtained about $10 \%$ weight loss for silicon panels, referring to degradation of the EVA.

Physical methods can be used to concentrate silver and silicon, and to reduce the consumption of chemical reagents. It is known that the major components of $\mathrm{c}-\mathrm{Si}$ panels, including glass, aluminum, and copper, can be recovered with cumulative yields greater than $85 \%$, relative to panel mass, through purely mechanical separation. It is understood that physical treatments such as crushing and grinding have the advantage of being inexpensive and allowing direct glass recovery. However, they cannot achieve the recovery of high-value materials such as silver, which requires more elaborate treatments. However, without a combination of thermal, chemical, or metallurgical steps, the impurity levels of the recovered materials could be high enough to reduce resale prices (Latunussa et al., 2016; Sander et al., 2007). Another concern is that crushing and grinding produce a large amount of dust and noise pollution (Xu et al., 2018).

Thermal decomposition is commonly used to separate material layers and remove polymers, as well as to recover materials such as glass, silicon, silver and copper (Dias et al., 2017; Fiandra et al., 2019; Gustavsson et al., 2006; Wang et al., 2012). Polymers thermal degradation should be performed in conjunction with an industrial-scale air pollution treatment system due to emissions (Huber et al., 2009).

Danz et al. (2019) studied the pyrolysis of PVF from the backsheet. The authors observed that the main pyrolysis reactions occurred between $400^{\circ} \mathrm{C}$ and $500^{\circ} \mathrm{C}$ and that temperature increases beyond the upper bound did not produce a significant mass loss. Farrell et al. (2019) looked at the effect of pyrolysis on EVA backsheet and two-stage decomposition was observed. In the first stage in which a temperature range was from 310 to $390^{\circ} \mathrm{C}$, there was the removal of acetic acid from the vinyl acetate monomer within the EVA structure, with a mass loss of approximately $22.6 \mathrm{wt} . \%$. In the secondary stage, at a temperature range of $410-510^{\circ} \mathrm{C}$, there was a mass loss of $75.7 \mathrm{wt} . \%$. Prado (2019) reported that $80 \%$ of the backsheet from the PV module was decomposed between 400 and $500^{\circ} \mathrm{C}$ in a nitrogen atmosphere. Dias et al. (2017) also evaluated the pyrolysis of the polymers from $\mathrm{PV}$ modules and reported that $75 \mathrm{wt} . \%$ was degraded when it reached $500^{\circ} \mathrm{C}$ in a nitrogen atmosphere.

Fiandra et al. (2018) compared the mass loss of thermal degradation under inert atmosphere (nitrogen) and oxidizing atmosphere (air). The authors reported that the oxygen present in an atmosphere can accelerate the process of EVA and backsheet degradation. Thus, because of this and the lower costs, it was decided to work with an oxidizing atmosphere (ambient air). Under oxidizing conditions, it was observed that heat treatment at $450^{\circ} \mathrm{C}$ was significantly less efficient than at 500 and $600^{\circ} \mathrm{C}$. However, there was no significant difference between 500 and $600^{\circ} \mathrm{C}$. The optimal operating conditions were $500^{\circ} \mathrm{C}$ and oxidizing atmosphere with a dwell time of $1 \mathrm{~h}$.

Right after thermal treatment of non-comminuted PV samples, Fiandra et al. (2018) and Fiandra et al. (2019) 
used sieves with different size apertures to separate the material obtained into three fractions: copper ribbons, glass and silicon. However, these papers do not detail how many or which sieves were used. In order to recycle polycrystalline silicon, amorphous silicon and CdTe PV panels, Granata et al. (2014) used 5 different sieves $(8 \mathrm{~mm}, 5 \mathrm{~mm}$, $1 \mathrm{~mm}, 0.4 \mathrm{~mm}, 0.08 \mathrm{~mm}$ ) after crushing operations and thermal treatment.

Pagnanelli et al. (2017) utilized sieving after mechanical treatment, i.e., a triple crushing, obtaining three fractions: an intermediate fraction $(0.4-1 \mathrm{~mm})$ of directly recoverable glass (17 wt.\%); a coarse fraction (>1 $\mathrm{mm}$ ) requiring further thermal treatment in order to separate EVAglued layers in glass fragments; a fine fraction $(<0.4 \mathrm{~mm})$ requiring chemical treatment to dissolve metals and obtain another recoverable glass fraction.

Dias et al.(2016) studied two methods to concentrate silver from waste modules. In the first method, the modules were milled, sieved, and leached in nitric acid solution with sodium chloride. In the second method, PV modules were milled, sieved, subjected to pyrolysis at $500^{\circ} \mathrm{C}$, and leached in nitric acid solution with sodium chloride.

Weckend et al. (2016) explained that sieves are one of the typical pieces of equipment used in panel recycling to separate impurities and other materials such as glass. Magnets, crushers, eddy-current devices, optical sorters, inductive sorters, and exhaust systems are also used. Nevertheless, sieving systems are often used to separate materials from other waste electrical and electronic equipment, such as LEDs (Cenci et al., 2021), Li-ion batteries (Granata et al., 2012), portable batteries (Bernardes et al., 2004) and cell phones (Kasper, 2011).

The removal of the polymers results in cleaner silicon without the presence of organic matter. Thus, it is important to define better thermal parameters that result in more concentrated materials. The objective of this study was to define parameters such as atmosphere type, temperature and time to be used in thermal treatment, aiming at the degradation of polymers and the concentration of materials, especially silver, because the recovery of this precious metal is important to add economic value to make recycling feasible. This work studied how the thermal treatment time influences the mass loss (degraded polymers) and the chemical composition of the obtained material fractions.

\section{MATERIALS AND METHODS}

In Figure 1, the methodology applied in this work is outlined. Preliminary results of this work were presented at the Fifth Symposium on Urban Mining and Circular Economy Virtual Event held on November 18 - 20, 2020. The full paper was published in the proceedings of SUM 2020 (ISBN: 9788862650236). In this study, a donated cracked polycrystalline silicon PV module was used. The unit was manufactured in 2018. It had a mass of $22 \mathrm{~kg}$ and dimensions of $1956 \mathrm{~mm}$ x $992 \mathrm{~mm} \times 40 \mathrm{~mm}$.

\subsection{Characterization}

The object of this work was the c-Si PV laminate, that is, module without frame and junction box. Thus, the first step was manual dismantling to remove the aluminum frame and the junction box.

\subsubsection{Chemical Analysis}

Subsequently, the c-Si PV laminate was fragmented into smaller pieces so that it would fit in the mill. The fragments from the laminate were comminuted in a knife mill, using a screen with $1 \mathrm{~mm}$ opening. The knife mill used was the SM300 model of the Retsch brand (Figure 2a). For characterization, $500 \mathrm{~g}$ of sample was ground, at $1500 \mathrm{rpm}$, until it reached a particle size less than $1.0 \mathrm{~mm}$ (verified in bench sieves). To ensure homogeneity and representativeness, the ground PV laminate was quartered (Figure $2 b$ ), and subsequently, three samples were analyzed (twice each sample) by X-ray fluorescence analysis (XRF). The portable analyzer used was a Thermo Nilton XL3t model of the Thermo Scientific brand (Figure 2c).

In the XRF analysis performed in this work, it was not possible to identify elements with atomic mass less than 12 , such as hydrogen, oxygen and carbon. Thus, in this paper, we will identify this category as "Unidentified Elements" (UE). Polymers are mostly composed of these elements. Thus, the mass of the polymers present is included in this category when analyzed by XRF. Glass is composed mainly of $\mathrm{SiO}_{2}$ and, consequently, part of its mass is also unidentified by the equipment. "X-ray diffraction analysis" (XRD) is required to differentiate the silicon from the glass and the crystalline silicon from the PV cell by chemical analysis. However, it is possible to visually differentiate these materials in the samples.

Furthermore, the white backsheet composed of polymers was also removed manually and separately characterized. The white backsheet composed of polymers was chemically identified using Fourier Transform Infrared Spectroscopy Analysis (FTIR). The FTIR Spectrophotometer used was a Spectrum 1000 model of the Perkin Elmer brand. The identification of these polymers is important to indicate the possible gaseous emissions of the studied processing route, based on the scientific literature.

\subsubsection{Thermogravimetric Analysis}

Three Thermogravimetric Analysis (TGA) were carried out to determine what is the ideal temperature for thermal treatment and what is the best atmosphere (inert or oxidizing) to be used. The thermogravimetric equipment used was the model Q50 of TA Instruments brand.

Thus, in the first stage, the backsheet material samples were subjected to TGA under two different atmospheres in order to verify which atmosphere would provide the greatest thermal decomposition. Inert atmosphere (gaseous nitrogen) was used in one sample. In another sample oxidizing atmosphere (synthetic air) was used.

After this preliminary analysis, a third sample of the ground PV laminate was also analyzed by TGA. In this stage, sample comminuted (particle size $1 \mathrm{~mm}$ ) was then quartered to guarantee homogeneity, and a $10 \mathrm{mg}$ sample was analyzed. This analysis allowed to determine the temperature of the highest thermal degradation, which was chosen as the operating temperature for the thermal treatment. 


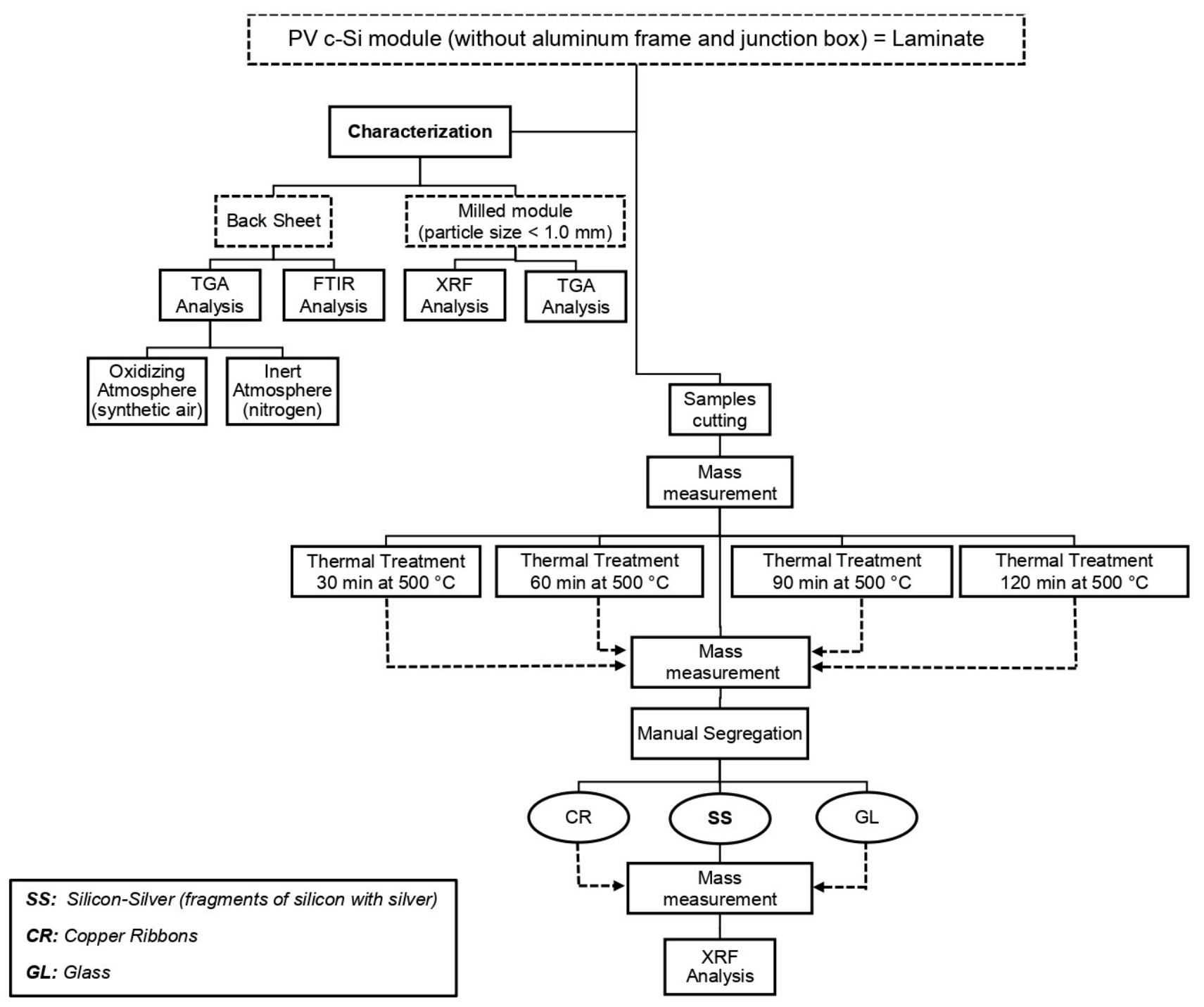

FIGURE 1: Flowchart of the general methodology applied in the work.

The three analyses were performed with a heating rate of $20^{\circ} \mathrm{C} / \mathrm{min}$, and the peak temperature was $940^{\circ} \mathrm{C}$.

\subsection{Thermal Degradation and Silver Concentration}

The objective to work with thermal treatment on samples without comminution was to degrade the polymers present and separate the layers from PV cells. In this study, the samples used were $8 \mathrm{~cm} \times 8 \mathrm{~cm}$ (Figure 3a), with an average mass of $57.33 \mathrm{~g}$ and a standard deviation of 2.27 g. Each sample was deposited in a ceramic crucible with the polymeric back layer facing upwards (Figure $3 b$ ), under an oxidizing atmosphere (ambient air), and heating rate of $9^{\circ} \mathrm{C} / \mathrm{min}$ from an initial temperature of $50^{\circ} \mathrm{C}$. The thermal treatment was carried out in a Sanchis $\mathrm{N} 1100 \mathrm{H}$ furnace (Figure $3 \mathrm{c}$ ), installed inside an extractor with a gas suction system.

At the operating constant temperature $\left(500^{\circ} \mathrm{C}\right)$, determined by TGA analysis, different times of residence in the furnace were tested $(30,60,90$ and $120 \mathrm{~min}$.). All tests were performed in triplicate. After $24 \mathrm{~h}$ inside the turnedoff furnace, the samples reached room temperature. The mass of the sample was then measured. Thus, the mass reduction relative to the original sample was calculated to understand the relationship between time and the degradation of polymeric matter, in mass percentage.

Subsequently, the glass (GL) and copper ribbon (CR) fractions, visually identified by color difference, were manually separated from the fraction composed of silicon fragments (with a printed matrix of silver paste) and residual polymers (SS). All fractions had their masses measured to calculate the percentage mass relation. The SS samples (totaling 12 samples) were macerated and analyzed by XRF (three measurements for each sample). The silver concentrations of the ground PV laminate were compared with the SS samples from the furnace times applied (30, 60,90 and $120 \mathrm{~min}$ at $500^{\circ} \mathrm{C}$ ).

In addition, statistical tests were applied to analyze and compare the percentage values of thermal degradation of the 4 residence times studied. The procedure used is described in detail in the works of Callegari-Jacques (2003), Scheff (2016) and Hoffman (2019). The parameters submitted to the statistical analysis were the "Percentages of 

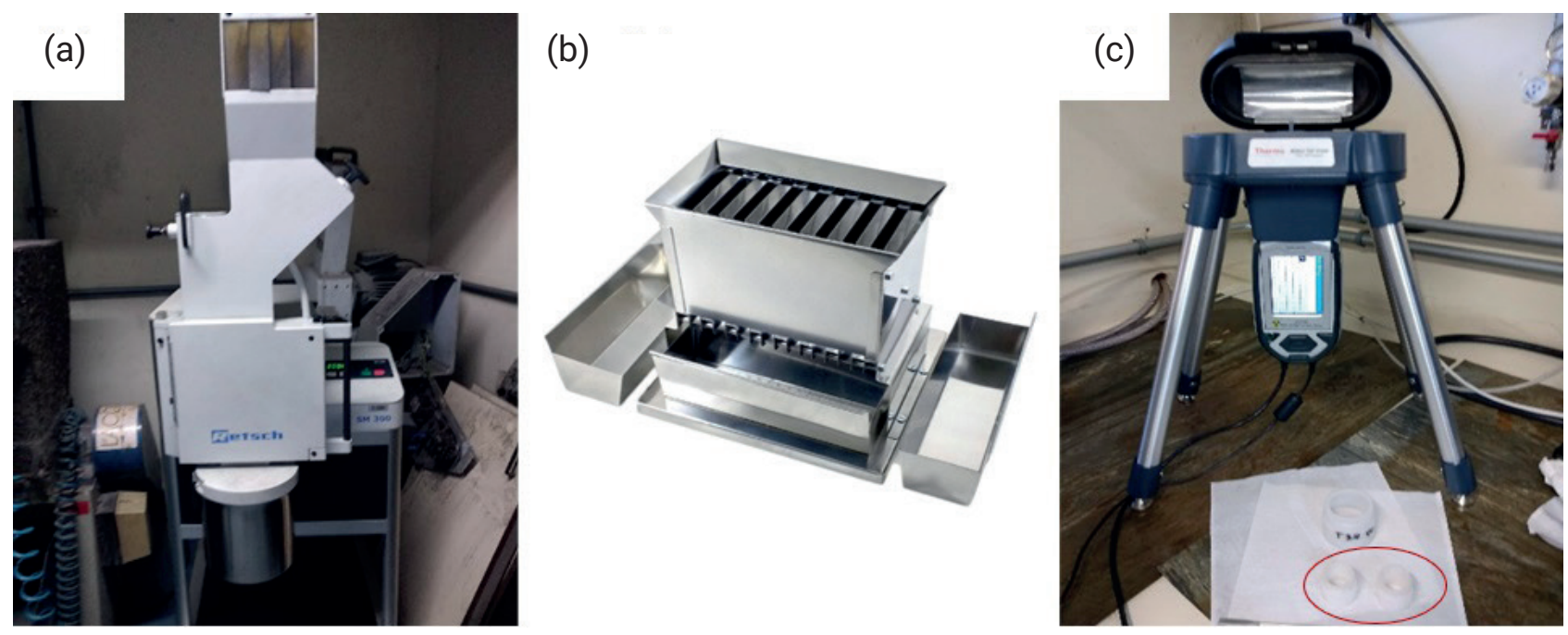

FIGURE 2: Metal content characterization (a) knife mill (b) stainless steel sample quarters (c) portable XRF analyzer and sample storage capsules for analysis, highlighted in red.
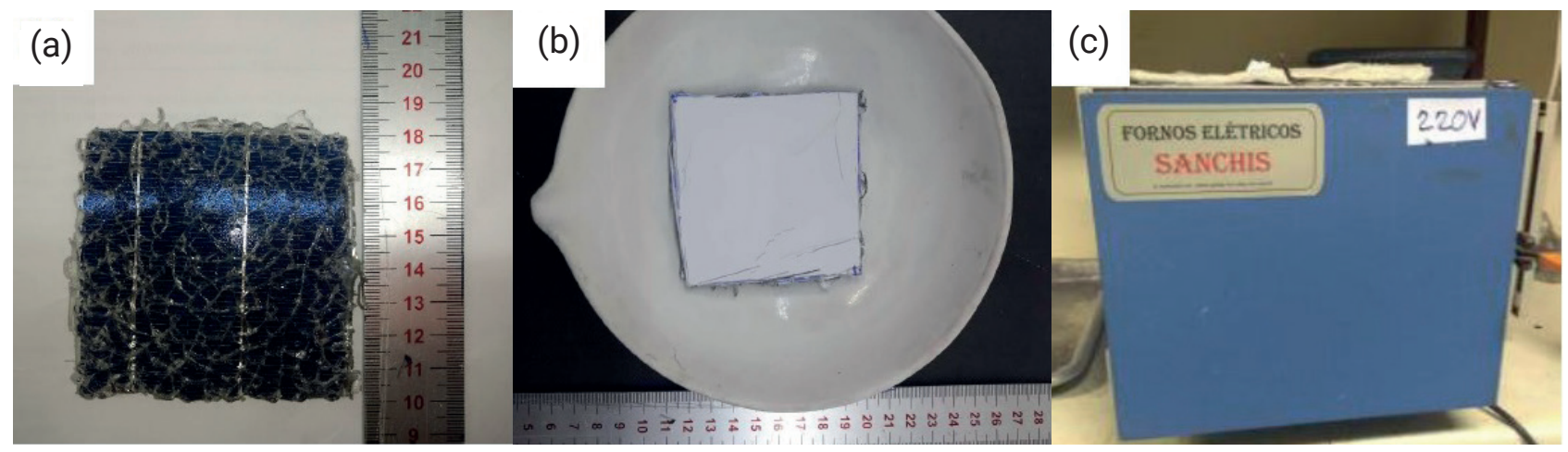

FIGURE 3: (a) Sample with dimensions $8 \times 8 \mathrm{~cm}$ (b) Sample before heat treatment in a ceramic crucible (c) Sanchis N1100H furnace.

Thermal Degradation" for each of "Thermal Time Lengths (minutes)",i.e., 30, 60, 90, and 120 minutes. The ANOVA test (parametric condition) and the Kruskal-Wallis test (non-parametric condition) are indicated for comparison between sample groups. The special conditions for performing the ANOVA test are homogeneity between the variances of the sample groups and the normal distribution of the data. If these conditions are satisfied by the Shapiro-Wilk (normality check) and Levene (homogeneity of variances check) tests, the ANOVA test can be performed. Otherwise, the comparison between sample groups should be performed by the non-parametric Kruskal-Wallis method.

Once the ANOVA and Kruskal-Wallis tests result in non-similarity between the sample groups analyzed, multiple comparison tests should be performed to define which sample group is significantly different from the others and whether it is considered larger or smaller. Callegari-Jacques (2003), Scheff (2016) and Hoffman (2019) indicated Tukey's multiple comparison test for the parametric data condition and Dunn's multiple comparison test for the non-parametric condition. The tests were performed at a $95 \%$ confidence level, where $p$-value conditions greater or less than 0.05 indicate acceptance of the null hypothesis or rejection, respectively. Minitab 17 software was used to perform the tests.

\section{RESULTS AND DISCUSSION}

\subsection{Characterization}

\subsubsection{Chemical Analysis}

As shown in Table 1, the average silver concentration detected in this study was $151.1 \pm 9.1 \mathrm{ppm}$, which can be considered low even compared to others works. The amount of silver found was closer to the values of Pagnanelli et al. (2017), $77.8 \mathrm{ppm}$, and Tao et al. (2020), 60 ppm. These studies reported lower silver concentrations. Jung et al. (2016) reported an intermediate silver amount, while Latunussa et al. (2016) and Dias et al. (2016) found higher concentrations. The cited studies report a range of silver concentrations from 60 to 632 ppm, i.e., a 10-fold variation.

Factors such as the PV panel brand, country of origin, year of manufacture, among others, can contribute for explain this wide variation in the reported silver concentrations. This fact is corroborated by some studies. According to Peeters et al. (2017), there is a tendency for the concentration to decrease over time. For example, modules manufactured in 2000 had 2,182 ppm silver, while in 2015, it had 
TABLE 1: Elemental concentrations of the ground PV laminate, obtained by XRF analysis, compared with data from other studies.

\begin{tabular}{|c|c|c|c|c|c|c|}
\hline \multicolumn{2}{|c|}{ Ground PV Laminate } & $\begin{array}{l}\text { Dias et al. } \\
(2016)\end{array}$ & $\begin{array}{c}\text { Latunussa et al. } \\
\qquad(2016)\end{array}$ & $\begin{array}{l}\text { Jung et al. } \\
(2016)\end{array}$ & $\begin{array}{c}\text { Pagnanelli et al. } \\
\text { (2017) }\end{array}$ & $\begin{array}{c}\text { Tao et al. } \\
(2020)\end{array}$ \\
\hline \multicolumn{7}{|c|}{ Valuable Metals (ppm) } \\
\hline $\mathrm{Ag}$ & $151.1 \pm 9.1$ & 632 & 530 & 378.9 & 77.8 & 60 \\
\hline $\mathrm{Cu}$ & $1530.8 \pm 27.6$ & 2984 & $\mathrm{NI}$ & 6660.0 & 18.8 & 6.000 \\
\hline \multicolumn{7}{|c|}{ Majority Elements (wt.\%) } \\
\hline UE & $58.1 \pm 2.7$ & $\mathrm{NI}$ & $\mathrm{NI}$ & $\mathrm{NI}$ & $\mathrm{NI}$ & $\mathrm{NI}$ \\
\hline Si & $31.7 \pm 1.7$ & $\mathrm{NI}$ & $\mathrm{NI}$ & $\mathrm{NI}$ & $\mathrm{NI}$ & $\mathrm{NI}$ \\
\hline $\mathrm{Ca}$ & $6.9 \pm 0.5$ & $\mathrm{NI}$ & $\mathrm{NI}$ & $\mathrm{NI}$ & $\mathrm{NI}$ & $\mathrm{NI}$ \\
\hline $\mathrm{Mg}$ & $0.8 \pm 0.2$ & $\mathrm{NI}$ & $\mathrm{NI}$ & $\mathrm{NI}$ & $\mathrm{NI}$ & $\mathrm{NI}$ \\
\hline \multicolumn{7}{|c|}{ Minority Elements (ppm) } \\
\hline $\mathrm{Fe}$ & $3626.1 \pm 53.1$ & $\mathrm{NI}$ & $\mathrm{NI}$ & $\mathrm{NI}$ & 870,2 & $\mathrm{NI}$ \\
\hline $\mathrm{Ti}$ & $1482.7 \pm 16.6$ & $\mathrm{NI}$ & $\mathrm{NI}$ & $\mathrm{NI}$ & 26.2 & $\mathrm{NI}$ \\
\hline $\mathrm{Sb}$ & $1194.5 \pm 161.0$ & $\mathrm{NI}$ & $\mathrm{NI}$ & $\mathrm{NI}$ & $\mathrm{NI}$ & $\mathrm{NI}$ \\
\hline Sn & $552.9 \pm 77.1$ & 558 & $\mathrm{NI}$ & $\mathrm{NI}$ & $\mathrm{NI}$ & 1.200 \\
\hline $\mathrm{Pb}$ & $353.4 \pm 39.1$ & 418 & $\mathrm{NI}$ & 211.6 & $\mathrm{NI}$ & $<1.000$ \\
\hline $\mathrm{Ni}$ & $183.7 \pm 19.0$ & $\mathrm{NI}$ & $\mathrm{NI}$ & $\mathrm{NI}$ & $\mathrm{NI}$ & $\mathrm{NI}$ \\
\hline $\mathrm{Zn}$ & $43.9 \pm 8.1$ & $\mathrm{NI}$ & $\mathrm{NI}$ & $\mathrm{NI}$ & 450.3 & $\mathrm{NI}$ \\
\hline
\end{tabular}

NI: Not Informed

UE: Unidentified Elements by XRF Analysis. They are elements with atomic mass less than 12, such as hydrogen, oxygen, and carbon

1239 ppm (Soltech, 2016). Weckend et al. (2016) also emphasized that the trend is to reduce the application of these metals in PV, stating that less than $0.1 \%$ of the module is composed of silver and other metals (mainly tin and lead).

Furthermore, $1530.8 \pm 27.6 \mathrm{ppm}$ of copper was detected in the ground PV laminate of this study. Comparing the studies of various authors, it is observed that there is a high variation between the concentrations, from 18.8 to 10,000 ppm. However, most of the already cited studies showed values above 5,700 ppm. Peeters et al. (2017) explained that copper is expected to gradually replace silver in $\mathrm{c}-\mathrm{Si}$ panels, so it can be assumed that the copper content of PV panels will increase over time. The copper content comes mainly from the ribbons arranged on the PV cell to collect the generated power. These copper ribbons could be sent directly for recycling if they are separated from the rest.

Another important point was the detection of lead, a hazardous metal. The PV laminate studied showed 353.4 $\pm 39.1 \mathrm{ppm}$ of lead, and other cited works indicate values between 200 and 1000 ppm. The origin of the lead could be from lead-tin solders, used to join the copper ribbons to the PV cell. The tin concentration was $552.9 \pm 77.1$ ppm, i.e., 1.6 times higher than the amount of lead. Iron, titanium, antimony, nickel, and zinc also were detected. Concerning these metals, further studies and more precise analyses are needed for better chemical characterization. Howev$\mathrm{er}$, the purpose of this work is to have an easily measured comparison parameter, especially for silver, to evaluate the concentration capacity of the developed route.

The components detected in more proportion in the samples were the silicon $(31.7 \pm 1.7 \mathrm{wt} . \%)$ and unidentified elements (UE $=65.81 \pm 2.7 \mathrm{wt}$.\%). The silicon is used both as a component of the PV cell, as much as a component of glass, and can be differentiated by XRD. About 58 wt.\% (a high amount) is composed of unidentified elements. These elements can be from the polymeric fraction and the oxygen present in the silicon dioxide (the main component of glass). The removal of glass and polymer layers, and consequent reducing the $\mathrm{UE}$, can contribute to concentrating silver by physical methods. Besides, considerable quantities (\%) of calcium and magnesium also were detected in the ground samples, which are derived from glass.

Ethylene-vinyl acetate (EVA), polyvinyl fluoride (PVF or Tedlar ${ }^{\circledR}$ ) and polyethylene terephthalate (PET) were identified in backsheet composition by analysis of the FTIR spectrum (Figure 4).

Concerning EVA, the literature reports that ethylene absorption bands occur in $2920 \mathrm{~cm}^{-1}, 2850 \mathrm{~cm}^{-1}, 1470 \mathrm{~cm}^{-1}$, $720 \mathrm{~cm}^{-1}$ while vinyl acetate bands occur in $1740 \mathrm{~cm}^{-1}, 1240$ $\mathrm{cm}^{-1}, 1020 \mathrm{~cm}^{-1}$ and $610 \mathrm{~cm}^{-1}$ (Meszlényi \& Körtvélyessy, 1999). In Figure 4, it can be observed EVA bands in 2927 and $2856 \mathrm{~cm}^{-1}$ resulting from symmetrical and asymmetric $\mathrm{C}-\mathrm{H}$ stretching, in $1733,15 \mathrm{~cm}^{-1}$ caused by $\mathrm{C}=0$ stretching of the ester group, and in $1236,36 \mathrm{~cm}^{-1}$ due to $\mathrm{COO}$ stretching.

Regarding PVF, three characteristic peaks appear in $850 \mathrm{~cm}^{-1}, 1400 \mathrm{~cm}^{-1}$ e $1200 \mathrm{~cm}^{-1}$. The first two peaks happen due to the $\mathrm{C}-\mathrm{F}$ stretching vibration, whereas the third peak results from the $\mathrm{C}-\mathrm{C}$ bonding (Koenig \& Mannion, 1966; Zerbi \& Cortili, 1970). An absorption band from strong intensity was observed in 1000 at $1110 \mathrm{~cm}^{-1}$ (peak in 1116, $47 \mathrm{~cm}^{-1}$ ) due to $\mathrm{C}-\mathrm{F}$ stretching vibration, typical from PVF.

With respect to $P E T$, typical deformations exist in the regions of $2900 \mathrm{~cm}^{-1}$ referent to the $\mathrm{CH} 3$ group; $1715 \mathrm{~cm}^{-1}$ and another in $730 \mathrm{~cm}^{-1}$ relating to the $\mathrm{C}=0$ group. Also, there are peaks in $1460 \mathrm{~cm}^{-1}$ and $977 \mathrm{~cm}^{-1}$ which are corresponding to $E G$, as well as in $1250 \mathrm{~cm}^{-1}$ referent to the $(\mathrm{C}=0)-0$ group. The band at $725 \mathrm{~cm}^{-1}$ appears at lower frequencies than is usual for a benzene ring because of 


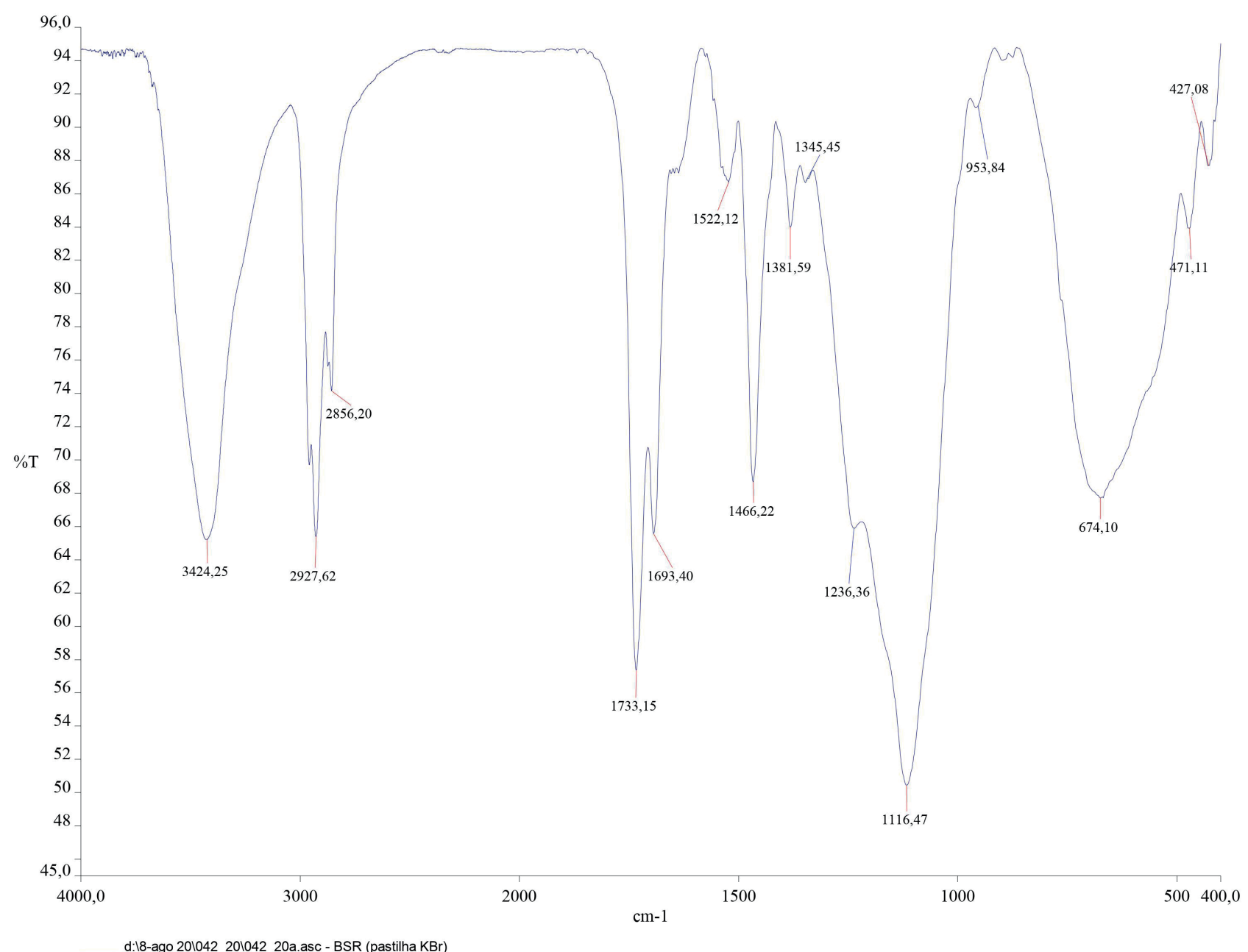

FIGURE 4: FTIR of the backsheet.

the extensive delocalization of the system of $\pi$-electron in the molecule, characterizing a para-substituted ring. When the ester group is attached to an aromatic ring, the $\mathrm{C}=0$ stretching vibration absorbs at lower frequencies, $1720 \mathrm{~cm}^{-}$ ${ }^{1}$. The aromatic part is easily identifiable by the $\mathrm{C}=\mathrm{C}$ stretching of the ring at 1150,1600-1500, $1235 \mathrm{~cm}^{-1}$ and one or more deformation modes at $850-700 \mathrm{~cm}^{-1}$. Two peaks are characteristic of the terephthalate in the region of the $\mathrm{C}-\mathrm{O}$ stretching vibration at 1110 and $1263 \mathrm{~cm}^{-1}$ (Santos, 2009). In Figure 4, the characteristic band of $\mathrm{C}-\mathrm{H}$ stretching from the aromatic ring may be visualized in approximately 3400 $\mathrm{cm}^{-1}$, The band at $2921 \mathrm{~cm}^{-1}$ is relative to the $\mathrm{CH} 2$ bonds, when the ester group is attached to an aromatic ring, and the $\mathrm{C}=\mathrm{O}$ axial strain absorbs at lower frequencies (in this case at $1717 \mathrm{~cm}^{-1}$ ). The aromatic part is easily identifiable by the $\mathrm{C}=\mathrm{C}$ deformation of the ring at $1600-1450 \mathrm{~cm}^{-1}$, and two characteristic peaks of the terephthalate in the region of the $\mathrm{C}-\mathrm{O}$ deformation at 1100 and $1300 \mathrm{~cm}^{-1}$.

This analysis was hindered because the backsheet is a multilayer material. In this case, some characteristic bands of materials may be overlapped and/or extended. However, this identification is corroborated by studies reported by other authors (Adothu et al., 2020; Aryan et al., 2018; Danz et al., 2019; Dias et al., 2017; Farrell et al., 2019; Huang et al., 2017; Peeters et al., 2017; Pinho \& Galdino, 2014; Sander et al., 2007).

\subsubsection{Thermogravimetric Analysis}

The backsheet samples used in the TGA were not comminuted. Instead, pieces were taken from the module and, therefore, well represented a PV laminate. Therefore, the TGA closely represents what would occur in the backsheet when kept intact in a thermal degradation.

Figure 5 shows that the backsheet lost 92.5 wt.\% of its mass at $500^{\circ} \mathrm{C}$ in a nitrogen atmosphere. The sample reached 95 wt. $\%$ of reduction at $900^{\circ} \mathrm{C}$, i.e., from $500^{\circ} \mathrm{C}$ onwards there was a slow decomposition. The module used in our study showed higher percentage values of thermal degradation than the other mentioned studies. However, it presented stages similar to those reported by other authors, that is, significant decomposition up to $500^{\circ} \mathrm{C}$ and slow degradation from that temperature onwards. The temperature of $500^{\circ} \mathrm{C}$ allows for the highest decomposition under nitrogen atmosphere for the polymers from the PV module (Dias et al., 2017), for backsheet (Prado, 2019), for PVF (Danz et al., 2019) and EVA (Farrell et al., 2019), as well as for the samples seen in our study (Figure 5).

In an oxidizing atmosphere (synthetic air), it can be 
seen in Figure 6 that there was an approximate reduction of $90 \mathrm{wt} . \%$ of the mass at $500^{\circ} \mathrm{C}$. When reaching $600^{\circ} \mathrm{C}$, the sample reached $97.5 \mathrm{wt} . \%$ of reduction. From $600^{\circ} \mathrm{C}$ to $900^{\circ} \mathrm{C}$ the curve stabilized. Therefore, in an oxidizing atmosphere, $97.5 \mathrm{wt} . \%$ of the mass was reduced at $600^{\circ} \mathrm{C}$, while in an inert atmosphere, 95 wt.\% of degradation was reached only at $900^{\circ} \mathrm{C}$. In both atmospheric conditions, there were two stages of decomposition.

The main thermal degradation products of PVF are HF (at $350^{\circ} \mathrm{C}$ ) and benzene $\left(\right.$ at $\left.450^{\circ} \mathrm{C}\right)$. PVF decomposes in the air at temperatures above $350^{\circ} \mathrm{C}$ by dehydrofluorination. Benzene is formed by chain scission and subsequent cyclization of PVF films at high temperatures but maintains considerable strength after thermal aging at $217^{\circ} \mathrm{C}$ (Drobny, 2001; Huber et al., 2009; Scheirs, 1997). The first stage of the curve can be attributed to these reactions.

Figure 7 shows the TGA analysis of the PV laminate under oxidizing conditions. As seen in Figure 7, the thermal degradation curve stabilized at $500^{\circ} \mathrm{C}$, with $20 \%$ of mass loss, referent to the polymeric fraction. Other authors have

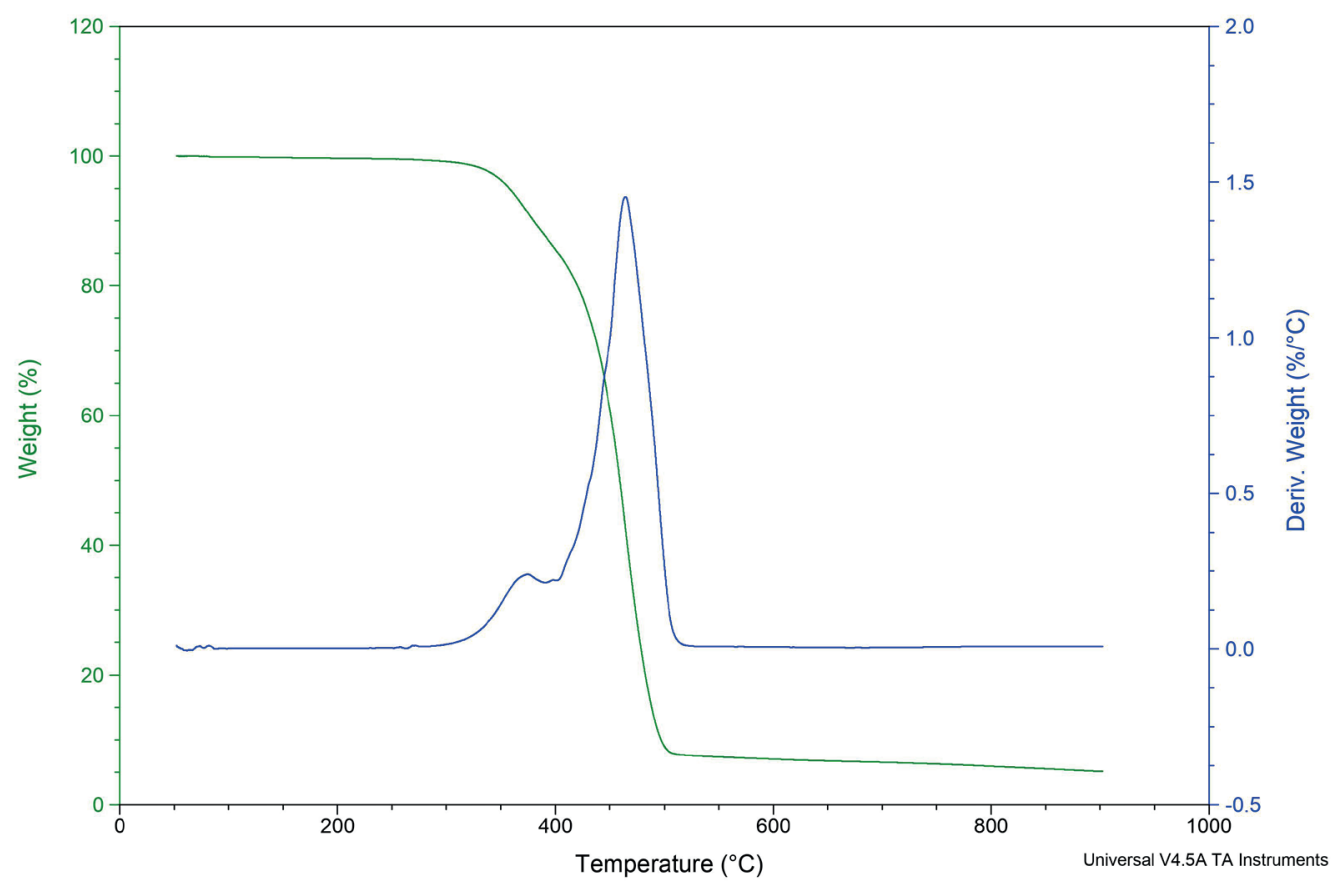

FIGURE 5: TGA of the backsheet under inert atmosphere (nitrogen gas).

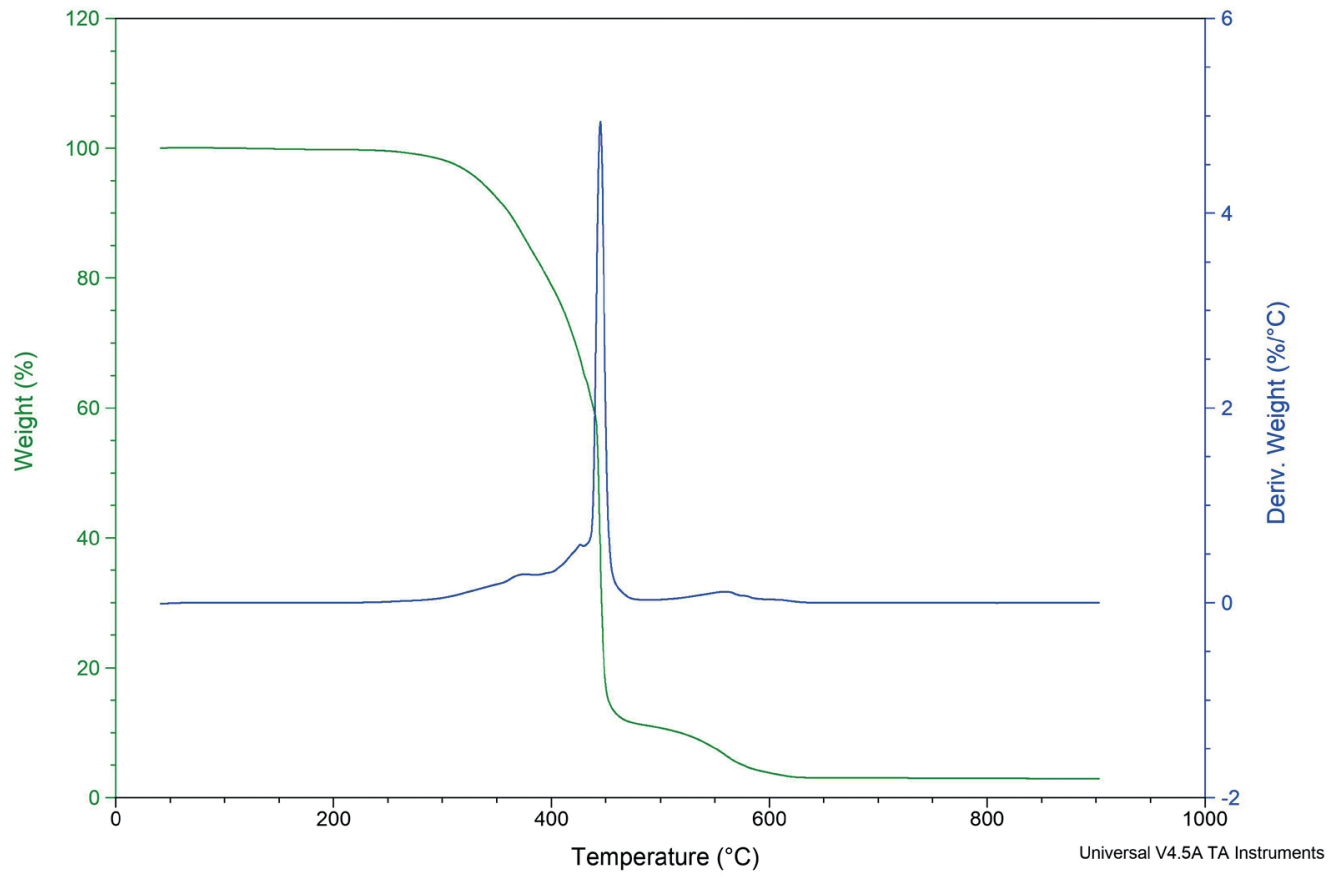

FIGURE 6: TGA of the backsheet under oxidizing atmosphere (synthetic air). 


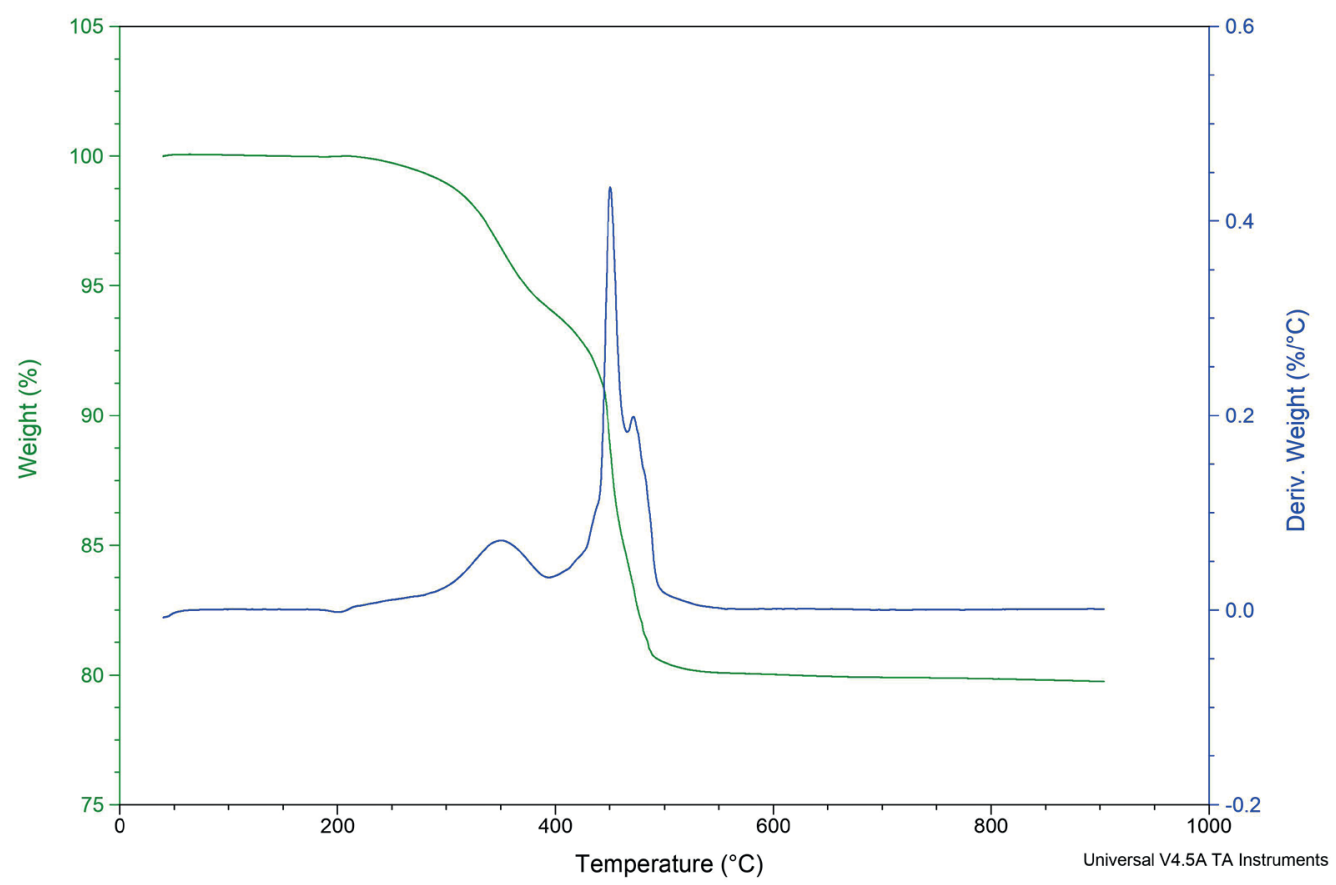

FIGURE 7: TGA of the ground PV laminate under oxidizing atmosphere (synthetic air).

also indicated $500^{\circ} \mathrm{C}$, in an oxidizing atmosphere (Fiandra et al., 2018) and a nitrogen atmosphere (Dias et al., 2017), as the ideal temperature for thermal degradation.

\subsection{Thermal Degradation and Silver Concentration}

In samples submitted to the 30 min of thermal treatment (at $500^{\circ} \mathrm{C}$ constant temperature), it was possible to observe the presence of dark-colored polymeric residues (Figure 8a). In samples submitted at heat treatment by 60 min (Figure $8 b$ ) or more, it was possible to observe that these residues have become white and have gradually decreased (Figure 8d). Thus, with the increase in the treatment time, the polymeric fraction was reduced and the sample stayed with a visually cleaner appearance. The removal of polymeric residues is necessary to purify the SS fraction. In a later stage of leaching silver with nitric acid, where the silicon fragments would be retained in the filtrate, the presence of polymers could reduce the quality of this recovered silicon. Considering that the TGA analysis identified that $20 \%$ of mass can be thermally degraded, values of mass loss must stay close to this level.

Table 2 shows the average percentage of thermally degraded mass as well as the percentages of the glass (GL), silicon-silver (SS). and copper ribbon (CR) fractions for each furnace dwelling time.

The thermal degradation followed by manual segregation increased the silver concentration concerning the ground PV laminate (Table 2), due to the removal of polymers, the glass fraction and copper ribbons. In SS samples, the average concentration was $3074.7 \pm 440.6 \mathrm{ppm}$, i.e., its concentration was approximately 20 times greater than the ground PV laminate (152.4 $\pm 9.1 \mathrm{ppm})$. According to Sverdrup et al. (2014), high concentration silver ore has 60 to $100 \mathrm{ppm}$ silver. Through the route presented, a con- centration 30 times higher than that present in the ore was obtained. Thus, with recycling PV modules, the demand for mining and its consequent impacts is reduced.

According to Table 2, the percentage values of lost mass ranged from $12.82 \pm 0.15 \mathrm{wt}$.\% to $13.62 \pm 0.02 \mathrm{wt} . \%$. Initially, increasing the oven time increased the percentage of the mass degraded (Table 2). By visual analysis, it was also possible to see that the amount of polymeric residue decreases as the thermal treatment time increases (Figure 8). According to the ANOVA test, there is a statistical difference in at least one of the sample groups ( $p$-value $=0.001$, accepting the alternative hypothesis of difference between sample groups). The Tukey test reports that the values for 90 and $120 \mathrm{~min}$ are similar to each other and higher than the others ( $p$-value $=0.062$, greater than 0.05 , accepting the null hypothesis of similarity between the sample groups). Thus, the statistical tests showed that the degradation stabilized at two longer times. The means of degraded mass for 90 and 120 min were the largest, although the 120-min samples visually showed less polymeric residue (Figure 8d). Possibly, the mass of these polymers present in the 90-min samples is so small that it does not result in significant differences. The 90-min application was indicated and justified to avoid unnecessary energy consumption. The sequence of tests and the respective results are presented in "APPENDIX - STATISTICAL ANALYSIS OF THERMAL DEGRADATION".

The TGA/DSC analysis of the ground module with the backsheet (Figure 7) shows that it is possible to thermally remove $20 \mathrm{wt}$.\% of the total mass. Despite the high energy consumption, maximum removal of about $13.62 \pm 0.02$ wt.\% was achieved, i.e., about $68 \%$ effectiveness. The presence of the backsheet may hinder the transport of heat and oxygen, reducing decomposition. As already mentioned, 

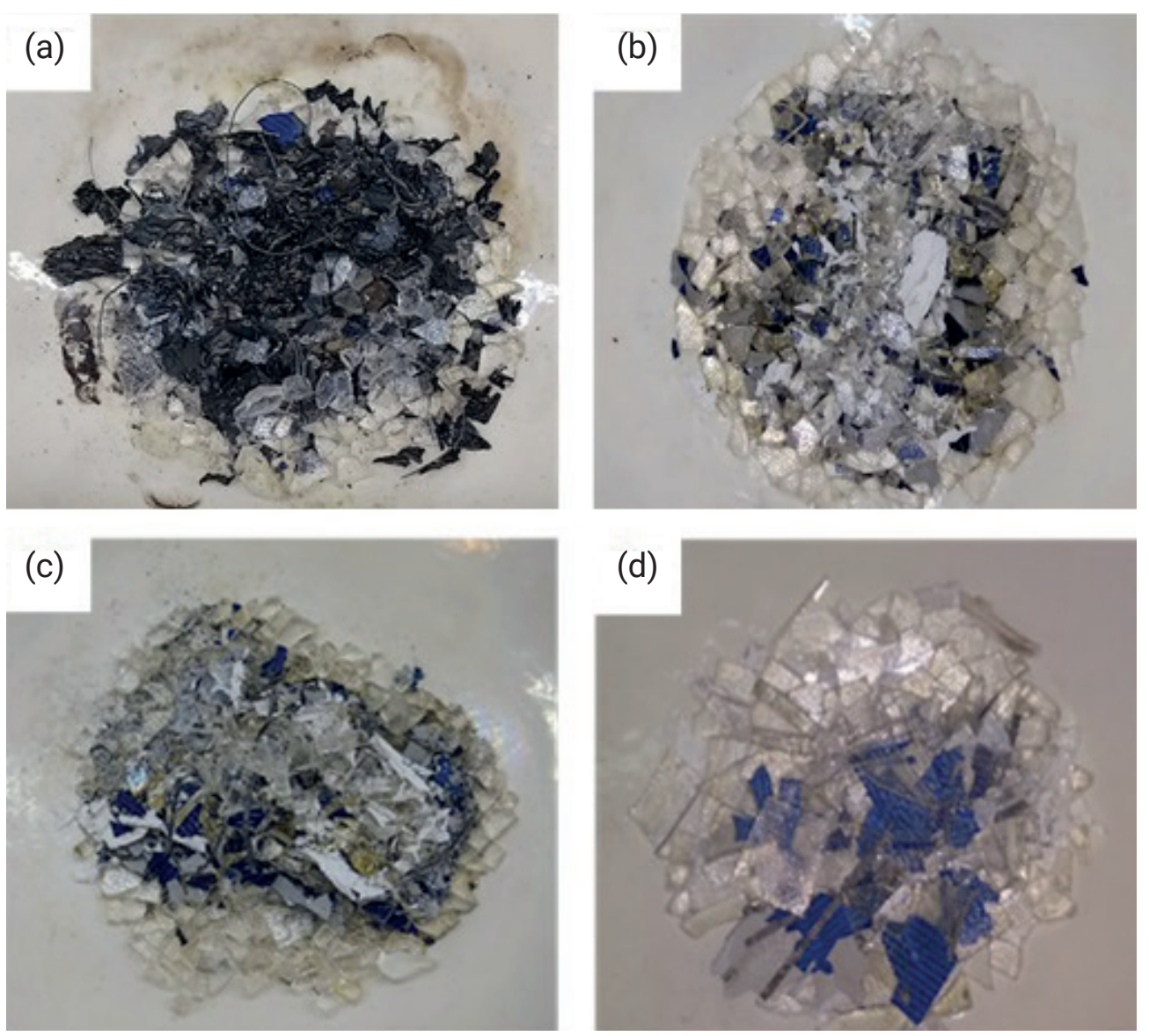

FIGURE 8: Different samples after furnace, which were kept at constant $500^{\circ} \mathrm{C}$ temperature for (a) $30 \mathrm{~min}$ (b) $60 \mathrm{~min}$ (c) $90 \mathrm{~min}$ (d) 120 min.

the backsheet is composed of PVF and its burning generates $\mathrm{HF}\left(350^{\circ} \mathrm{C}\right)$ and benzene $\left(450^{\circ} \mathrm{C}\right)$ (Huber et al., 2009), in addition to dioxins and furans. Therefore, removing the backsheet before burning could result in benefits such as more silicon purification, reduced furnace time and lower toxic emissions.

The fractions obtained after heat treatment showed similar percentage amounts, as shown in Table 2. The samples showed average percentage values of $6.23 \pm 0.19$ wt.\% for SS. Fiandra et al. (2019) recovered 6.37 wt.\% of the equivalent fraction. This value not only reflects the amount of silicon but also a load of undecomposed polymers. Therefore, a higher decomposition will result in a lower percentage.

An average value of $79.37 \pm 0.43$ wt.\% of glass was obtained GL fraction. Other studies have indicated 70 wt.\%

TABLE 2: Silver concentrations ( $\mathrm{ppm}$ ) for the ground PV laminate and SS samples for the furnace times applied at $500^{\circ} \mathrm{C}$. Percentage mass removed after thermal degradation related to the decomposition of the polymers present. Percentage Mass of Fractions SS, CR and $\mathrm{GL}$ obtained in the samples after the furnace.

\begin{tabular}{|c|c|c|c|c|c|}
\hline & Silver (ppm) ${ }^{c d}$ & $\%$ Lost Mass ${ }^{\mathrm{e}}$ & wt. $\%$ SS $^{f}$ & wt. $\% \mathrm{CR}^{\mathrm{f}}$ & wt. $\% \mathrm{GL}^{f}$ \\
\hline Ground PV Laminate a & $152.4 \pm 9.1$ & Not applicable & Not applicable & Not applicable & Not applicable \\
\hline $30 \mathrm{~min}$ at $500^{\circ} \mathrm{C}^{\mathrm{b}}$ & $2990.6 \pm 288.5$ & $12.82 \pm 0.15$ & $6.21 \pm 0.29$ & $1.07 \pm 0.20$ & $79.90 \pm 0.33$ \\
\hline $60 \mathrm{~min}$ at $500^{\circ} \mathrm{C}^{\mathrm{b}}$ & $3135.2 \pm 469.2$ & $13.18 \pm 0.16$ & $6.12 \pm 0.17$ & $1.38 \pm 0.21$ & $79.32 \pm 0.29$ \\
\hline $90 \mathrm{~min}$ at $500^{\circ} \mathrm{C}^{\mathrm{b}}$ & $2934.9 \pm 509.1$ & $13.62 \pm 0.02$ & $6.38 \pm 0.16$ & $1.04 \pm 0.11$ & $78.96 \pm 0.04$ \\
\hline $120 \mathrm{~min}$ at $500^{\circ} \mathrm{C}^{\mathrm{b}}$ & $3280.7 \pm 422.8$ & $13.28 \pm 0.17$ & $6.24 \pm 0.06$ & $1.22 \pm 0.22$ & $79.27 \pm 0.42$ \\
\hline
\end{tabular}

SS: Silicon fragments with a printed matrix of silver paste and residual polymers

CR: Copper ribbon

GL: Glass

a Polycrystalline silicon module without aluminum frame and junction box that was ground in a knife mill - particle size smaller than $1 \mathrm{~mm}$.

${ }^{b}$ Silver concentration for the SS (Silicon-Silver) sample, after maceration.

${ }^{c} \mathrm{X}$-ray Fluorescence Analysis.

${ }^{d}$ Ore with a high concentration of silver has 60-100 ppm of this element, according to (Sverdrup et al., 2014).

${ }^{e}$ Regarding the decomposition of the polymeric fraction, after furnace treatment.

${ }^{f}$ Mass percentages of the manually segregated fraction. 
(Latunussa et al., 2016),71.20 wt.\% (Fiandra et al., 2019), 74.16 wt.\% (Fiandra et al., 2018), and 74 wt.\% (Tao et al., 2020), of glass present in the PV modules. An average value of $1.19 \pm 0.22 \mathrm{wt}$.\% of copper ribbons was obtained in the CR fraction, while Fiandra et al. (2019) recovered 0.51 wt.\% to ribbons.

In this work, the segregation of the fractions was performed manually on a laboratory bench. However, it is necessary to study methods applicable on an industrial scale. The glass fragments could be segregated by suction cups and sieving systems, while copper ribbons could be separated by electrostatic separation (Dias et al., 2018). Silicon fragments break easily, which reduces their size, so they could be separated by sieving as well.

Table 3 presents the concentrations of silver, copper, unidentifiable elements (UE), silicon, lead and tin of the SS fractions according to furnace times, compared to the composition of the ground PV laminate. UE are the elements with atomic mass less than 12, such as hydrogen, oxygen, and carbon, which were not identified by the XRF equipment that was being used.

Besides the silver increment, a reduction of about 5.6 to 16.4 times in the amount of copper present in the SS fraction was observed because this material stayed in the $\mathrm{CR}$ fraction after the manual separation. It was also possible to observe an increase in the amount of silicon (1.7 to 1.8 fold) and a reduction in the mass of unidentified elements (1.8 to 2.1 fold). The increase in the degraded percentage was consistent with the reduction in unidentified elements. The UE ratios by percent decomposition were 2.4 for 30 min, 2.2 for $60 \mathrm{~min}, 2.0$ for $90 \mathrm{~min}$, and 2.2 for 120 minutes. Other elements that were also more concentrated in the SS fraction were lead and tin. Despite the removal of the copper ribbons, the lead amount increased 3.0 to 4.6 times, and tin increased 3.0 to 3.6 times. In a study about the composition of Si cells extracted from modules (in weight percent), Tao et al. (2020) reported that $2.9 \%$ of composition was tin and $2.4 \%$ was lead. So, it is important to develop methods for these metals to be removed from the SS fraction, since this fraction, subsequently, will undergo an acidic leaching process to recover the silver.

The GL fraction is composed of fragments of tempered glass from the PV laminate. As seen in Table 4, the concentrations of the GL fraction were not altered by the variation from 30 to $120 \mathrm{~min}$ in thermal treatment. Visually, the glass fragments were similar regardless of the thermal treatment time. The average composition was $67.03 \pm 1.02$ wt.\% of the unidentified elements, $25.41 \pm 0.83$ wt.\% of

TABLE 3: Composition of SS fractions, obtained by XRF analysis, compared to the ground PV laminate.

\begin{tabular}{|c|c|c|c|c|c|}
\hline \multicolumn{2}{|c|}{ Ground PV Laminate } & $\mathrm{SS}_{30 \mathrm{~m}}$ & $\mathrm{SS}_{60 \mathrm{~m}}$ & $\mathrm{SS}_{90 \mathrm{~m}}$ & $\mathrm{SS}_{120 \mathrm{~m}}$ \\
\hline \multicolumn{6}{|c|}{ Valuable Metals (ppm) } \\
\hline $\mathrm{Ag}$ & $151.1 \pm 9.1$ & $2990.6 \pm 288.5$ & $3135.2 \pm 469.2$ & $2934.9 \pm 509.1$ & $3280.7 \pm 422.8$ \\
\hline $\mathrm{Cu}$ & $1530.8 \pm 27.6$ & $93.5 \pm 6.9$ & $94.3 \pm 16.5$ & $119.7 \pm 28.3$ & $274.0 \pm 45.5$ \\
\hline \multicolumn{6}{|c|}{ Majority Elements (wt.\%) } \\
\hline UE & $58.1 \pm 2.7$ & $31.3 \pm 2.9$ & $29.4 \pm 3.6$ & $27.4 \pm 2.2$ & $28.9 \pm 2.3$ \\
\hline $\mathrm{Si}$ & $31.7 \pm 1.7$ & $52.7 \pm 1.4$ & $56.1 \pm 3.0$ & $56.8 \pm 3.1$ & $55.1 \pm 1.1$ \\
\hline \multicolumn{6}{|c|}{ Hazardous Metals (ppm) } \\
\hline $\mathrm{Pb}$ & $353.4 \pm 39.1$ & $1233.8 \pm 221.6$ & $1051.9 \pm 54.0$ & $1394.6 \pm 160.2$ & $1628.4 \pm 400.5$ \\
\hline Sn & $552.9 \pm 77.1$ & $2003.7 \pm 628.4$ & $1963.3 \pm 590.3$ & $1764.9 \pm 615.8$ & $1664.1 \pm 628.7$ \\
\hline
\end{tabular}

UE: Unidentified Elements by XRF Analysis. They are elements with atomic mass less than 12, such as hydrogen, oxygen, and carbon.

TABLE 4: Composition of GL fractions, obtained by XRF analysis, compared to the ground PV laminate.

\begin{tabular}{|c|c|c|c|c|c|}
\hline \multicolumn{2}{|c|}{ Ground PV Laminate } & $\mathrm{GL}_{30 \mathrm{~m}}$ & $\mathrm{GL}_{60 \mathrm{~m}}$ & $\mathrm{GL}_{90 \mathrm{~m}}$ & $\mathrm{GL}_{120 \mathrm{~m}}$ \\
\hline \multicolumn{6}{|c|}{ Valuable Metals (ppm) } \\
\hline $\mathrm{Ag}$ & $151.1 \pm 9.1$ & $9.5 \pm 1.9$ & $8.0 \pm 1.9$ & $8.1 \pm 1.6$ & $9.8 \pm 2.8$ \\
\hline $\mathrm{Cu}$ & $1530.8 \pm 27.6$ & $25.6 \pm 3.8$ & $21.1 \pm 3.6$ & $23.5 \pm 4.3$ & $20.5 \pm 4.1$ \\
\hline \multicolumn{6}{|c|}{ Majority Elements (wt.\%) } \\
\hline UE & $58.1 \pm 2.7$ & $66.8 \pm 0.7$ & $68.0 \pm 1.2$ & $66.7 \pm 0.6$ & $66.3 \pm 0.3$ \\
\hline $\mathrm{Si}$ & $31.7 \pm 1.7$ & $25.6 \pm 0.4$ & $24.5 \pm 1.0$ & $25.7 \pm 0.4$ & $25.9 \pm 0.2$ \\
\hline $\mathrm{Ca}$ & $6.9 \pm 0.5$ & $6.3 \pm 0.1$ & $6.1 \pm 0.1$ & $6.3 \pm 0.03$ & $6.3 \pm 0.03$ \\
\hline $\mathrm{Mg}$ & $0.8 \pm 0.2$ & $0.6 \pm 0.2$ & $0.7 \pm 0.2$ & $0.7 \pm 0.2$ & $0.8 \pm 0.1$ \\
\hline \multicolumn{6}{|c|}{ Hazardous Metals (ppm) } \\
\hline $\mathrm{Pb}$ & $353.4 \pm 39.1$ & $6.8 \pm 0.3$ & $8.2 \pm 2.2$ & $7.1 \pm 1.7$ & $7.6 \pm 0.5$ \\
\hline Sn & $552.9 \pm 77.1$ & $57.1 \pm 10.8$ & $71.8 \pm 5.0$ & $64.0 \pm 12.9$ & $56.5 \pm 19.7$ \\
\hline
\end{tabular}

UE: Unidentified Elements by XRF Analysis. They are elements with atomic mass less than 12, such as hydrogen, oxygen, and carbon. 
TABLE 5: Composition of CR fractions, obtained by XRF analysis, compared to the ground PV laminate.

\begin{tabular}{|c|c|c|c|c|c|}
\hline \multicolumn{2}{|c|}{ Ground PV Laminate } & $\mathrm{CR}_{30 \mathrm{~m}}$ & $\mathrm{CR}_{60 \mathrm{~m}}$ & $\mathrm{CR}_{90 \mathrm{~m}}$ & $\mathrm{CR}_{120 \mathrm{~m}}$ \\
\hline \multicolumn{6}{|c|}{ Majority Elements (wt.\%) } \\
\hline $\mathrm{Cu}$ & $0.153 \pm 0.003$ & $53.0 \pm 6.2$ & $51.8 \pm 7.7$ & $60.9 \pm 3.3$ & $56.6 \pm 1.9$ \\
\hline $\mathrm{Pb}$ & $0.035 \pm 0.004$ & $25.1 \pm 7.7$ & $28.0 \pm 9.5$ & $19.8 \pm 3.7$ & $19.3 \pm 3.6$ \\
\hline Sn & $0.055 \pm 0.008$ & $16.0 \pm 0.8$ & $15.2 \pm 3.1$ & $15.3 \pm 1.2$ & $18.1 \pm 0.6$ \\
\hline \multicolumn{6}{|c|}{ Other Elements (wt.\%) } \\
\hline $\mathrm{Ag}$ & $0.015 \pm 0.001$ & $2.4 \pm 0.3$ & $2.6 \pm 0.4$ & $2.1 \pm 0.4$ & $2.6 \pm 0.2$ \\
\hline $\mathrm{Si}$ & $31.73 \pm 1.66$ & $1.5 \pm 1.2$ & $1.0 \pm 0.6$ & $0.7 \pm 0.3$ & $1.0 \pm 0.6$ \\
\hline
\end{tabular}

silicon, $6.24 \pm 0.10$ wt. $\%$ of calcium, and $0.73 \pm 0.20$ wt. $\%$ of magnesium. These data show us how much the composition of the glass interferes in the general composition of the module because $79 \%$ of the PV laminate resulted in glass fragments (Table 2).

The amounts of copper and silver in the GL fraction found were proportionally small, $21.35 \pm 6.78 \mathrm{ppm}$ and 8.69 $\pm 2.13 \mathrm{ppm}$, respectively. The small silver amount found in the glass fragments may be from the fine dust of the SS fraction, which cannot be removed manually.

The composition of the CR fraction remained similar for all thermal treatment times (Table 5). The average composition was $55.69 \pm 6.39 \%$ copper, $23.17 \pm 7.51 \%$ lead, and $16.06 \pm 2.12 \%$ tin. As previously commented, lead and tin are used by solder copper ribbons on the PV cell, thus, its presence in this fraction is justified. Moreover, there was $2.41 \pm 0.39 \%$ silver and $0.47 \pm 0.06 \%$ silicon in this fraction. Considering that the CR fraction represents only $1 \mathrm{wt} . \%$ of the PV laminate, any amount of SS adhered to the surface of the ribbon will represent a considerable percentage in the total composition, higher than the concentration in the ground PV laminate.

\section{CONCLUSIONS}

When comparing the XRF analysis of the ground PV laminate with values from other authors, it was observed that the metal content of crystalline silicon PV modules varies. By FTIR analysis, the backsheet composition was identified as PVF, PET and EVA, which is consistent with studies by other authors. The TGA analysis revealed that the backsheet from PV reached higher percentages of thermal degradation in a lower temperature range, when under an oxidizing atmosphere. In an inert atmosphere, $92.5 \mathrm{wt} . \%$ of the backsheet was decomposed at $500^{\circ} \mathrm{C}$, and $95 \mathrm{wt} . \%$ at $900^{\circ} \mathrm{C}$. In an oxidizing atmosphere, $90 \mathrm{wt} . \%$ of the mass was reduced at $500^{\circ} \mathrm{C}$, but $97.5 \mathrm{wt} . \%$ at $600^{\circ} \mathrm{C}$. It was also observed that $20 \mathrm{wt} . \%$ of PV laminate was degraded at $500^{\circ} \mathrm{C}$, and from this temperature up to $900^{\circ} \mathrm{C}$, there was no mass loss.

The thermal treatment used in this study resulted in 3 fractions: silicon-silver (6.23 \pm 0.19 wt.\%), glass (79.37 \pm 0.43 wt.\%) and copper ribbons (1.19 \pm 0.22 wt.\%). It was also found that $13.62 \pm 0.02$ wt.\% of the polymer mass is degraded in 90 min of thermal treatment. The application of $120 \mathrm{~min}$ is not justified because it requires additional time and energy to obtain a statistically similar result ( $p$-value $=0.062$, greater than 0.05 , accepting the null hypothesis of similarity between the sample groups). Also, the adopted procedure concentrated silver from $152.4 \pm 9.1 \mathrm{ppm}$ to $3074.7 \pm 440.6 \mathrm{ppm}$ on average, an approximately 20 times increase in relation to the ground PV laminate.

The TGA/DSC analysis of the ground backsheet shows that, theoretically, it is possible to thermally remove 20 wt.\% of the total mass. However, in this study, maximum removal of about $13.62 \pm 0.02$ wt.\% was achieved, i.e., about $68 \%$ effectiveness. Although the treatment was effective in concentrating silver, other alternatives can be studied to reduce the thermal treatment time and reducing the environmental impact of burning PVF. The glass and copper ribbons fractions maintained similar compositions regardless of the thermal treatment time. The silicon-silver fraction also showed high concentrations of lead, which is a hazardous metal. Further studies are needed to separate and recover these metals.

\section{ACKNOWLEDGEMENTS}

This research is supported by the CNPQ - Conselho Nacional de Desenvolvimento Científico e Tecnológico and the other Brazilian government agencies CAPES, Finep and Fapergs.

\section{REFERENCES}

Adothu, B., Bhatt, P., Zele, S., Oderkerk, J., Costa, F. R., \& Mallick, S. (2020). Investigation of newly developed thermoplastic polyolefin encapsulant principle properties for the c-Si PV module application. Materials Chemistry and Physics, 243(January), 122660. https://doi.org/10.1016/j.matchemphys.2020.122660

Aryan, V., Font-Brucart, M., \& Maga, D. (2018). A comparative life cycle assessment of end-of-life treatment pathways for photovoltaic backsheets. Progress in Photovoltaics: Research and Applications, 26(7), 443-459. https://doi.org/10.1002/pip.3003

Bernardes, A. M., Espinosa, D. C. R., \& Tenório, J. A. S. (2004). Recycling of batteries: A review of current processes and technologies. Journal of Power Sources, 130(1-2), 291-298. https://doi. org/10.1016/j.jpowsour.2003.12.026

BiolS. (2011). Study on photovoltaic panels supplementing the impact assessment for a recast of the WEEE directive - Final report. (Issue April). http://ec.europa.eu/environment/waste/weee/pdf/ Study on PVs Bio final.pdf

Callegari-Jacques, S. M. (2003). Bioestatística: Princípios e aplicações. Artmed.

Cenci, M. P., Christ, F., Berto, D., Silva, P., Camargo, S., \& Veit, H. M. (2021). Separation and concentration of valuable and critical materials from wasted LEDs by physical processes. Waste Management, 120, 136-145. https://doi.org/10.1016/j.wasman.2020.11.023

Chancerel, P., Meskers, C. E. M., Hagelüken, C., \& Rotter, V. S. (2009) Assessment of Precious Metal Flows During Preprocessing of Waste Electrical and Electronic Equipment. Journal of Industrial Ecology, 13(5), 791-810. https://doi.org/10.1111/j.15309290.2009.00171.x 
Danz, P., Aryan, V., Möhle, E., \& Nowara, N. (2019). Experimental Study on Fluorine Release from Photovoltaic Backsheet Materials Containing PVF and PVDF during Pyrolysis and Incineration in a Technical Lab-Scale Reactor at Various Temperatures. Toxics, 7(3), 47. https://doi.org/10.3390/toxics7030047

DeBergalis, M. (2004). Fluoropolymer films in the photovoltaic industry. Journal of Fluorine Chemistry, 125(8), 1255-1257. https://doi. org/10.1016/j.jfluchem.2004.05.013

Deng, R., Chang, N. L., Ouyang, Z., \& Chong, C. M. (2019). A techno-economic review of silicon photovoltaic module recycling. Renewable and Sustainable Energy Reviews, 109(March), 532-550. https:// doi.org/10.1016/j.rser.2019.04.020

Deng, R., Chang, N., Lunardi, M. M., Dias, P., Bilbao, J., Ji, J., \& Chong, C. M. (2020). Remanufacturing end-of-life silicon photovoltaics: Feasibility and viability analysis. Progress in Photovoltaics: Research and Applications, pip.3376. https://doi.org/10.1002/pip.3376

Dias, P., Javimczik, S., Benevit, M., Veit, H., \& Bernardes, A. M. (2016) Recycling WEEE: Extraction and concentration of silver from waste crystalline silicon photovoltaic modules. Waste Management, 57, 220-225. https://doi.org/10.1016/j.wasman.2016.03.016

Dias, P. R., Javimczik, S., Benevit, M., \& Veit, H. (2017). Recycling WEEE: Polymer characterization and pyrolysis study for waste of crystalline silicon photovoltaic modules. Waste Management, 60, 716722. https://doi.org/10.1016/j.wasman.2016.08.036

Dias, P., Schmidt, L., Gomes, L. B., Bettanin, A., Veit, H., \& Bernardes, A M. (2018). Recycling Waste Crystalline Silicon Photovoltaic Modules by Electrostatic Separation. Journal of Sustainable Metallurgy, 4(2), 176-186. https://doi.org/10.1007/s40831-018-0173-5

Drobny, J. G. (2001). Technology of fluoropolymers. CRC Press.

Farrell, C., Osman, A. I., Zhang, X., Murphy, A., Doherty, R., Morgan, K., Rooney, D. W., Harrison, J., Coulter, R., \& Shen, D. (2019). Assessment of the energy recovery potential of waste Photovoltaic ( PV ) modules. Scientific Reports, 9(March), 1-13. https://doi. org/10.1038/s41598-019-41762-5

Fiandra, V., Sannino, L., Andreozzi, C., Corcelli, F., \& Graditi, G. (2019) Silicon photovoltaic modules at end-of-life: Removal of polymeric layers and separation of materials. Waste Management, 87, 97107. https://doi.org/10.1016/j.wasman.2019.02.004

Fiandra, V., Sannino, L., Andreozzi, C., \& Graditi, G. (2018). End-of-life of silicon PV panels: A sustainable materials recovery process. Waste Management, 84, 91-101. https://doi.org/10.1016/j.wasman.2018.11.035

Fthenakis, V. M. (2000). End-of-life management and recycling of PV modules. Energy Policy, 28(14), 1051-1058. https://doi. org/10.1016/S0301-4215(00)00091-4

Granata, G., Pagnanelli, F., Moscardini, E., Havlik, T., \& Toro, L. (2014). Recycling of photovoltaic panels by physical operations. Solar Energy Materials and Solar Cells, 123(2014), 239-248. https://doi. org/10.1016/j.solmat.2014.01.012

Granata, Giuseppe, Moscardini, E., Pagnanelli, F., Trabucco, F., \& Toro, L. (2012). Product recovery from Li-ion battery wastes coming from an industrial pre-treatment plant: Lab scale tests and process simulations. Journal of Power Sources, 206, 393-401. https://doi. org/10.1016/j.jpowsour.2012.01.115

Gustavsson, J. P. R., Segal, C., Dolbier, W. R., Ameduri, B., \& Kostov, G. (2006). Combustion and thermal decomposition of fluorinated polymers. Combustion Science and Technology, 178(12), 20972114. https://doi.org/10.1080/00102200600860681

Hoffman, J. I. E. (2019). Analysis of Variance. I. One-Way. In Basic Biostatistics for Medical and Biomedical Practitioners (pp. 391-417). Elsevier. https://doi.org/10.1016/B978-0-12-817084-7.00025-5

Huang, W.-H. H., Shin, W. J., Wang, L., Sun, W.-C. C., \& Tao, M. (2017) Strategy and technology to recycle wafer-silicon solar modules. Solar Energy, 144, 22-31. https://doi.org/10.1016/j.solener.2017.01.001

Huber, S., Moe, M., Schmidbauer, N., Hansen, G., \& Herzke, D. (2009) Emissions from the incineration of fluoropolymer materials. Nilu.

Insider. (2021). Copper price on Feb 26, 2021. https://markets.businessinsider.com/commodities/copper-price

IRENA. (2021a). Distribution of renewable energy technologies within a country, area or region of choice in relation to renewable energy power capacity and electricity generation figures. https://www.irena.org/Statistics/View-Data-by-Topic/Capacity-and-Generation/ Technologies
IRENA. (2021b). International Renewable Energy Agency - Statistics Time Series:Trends in Capacity and Generation of Renewable Energy:Trends in Capacity and Generation of Renewable Energy. https://www.irena.org/Statistics/View-Data-by-Topic/Capacity-and-Generation/Statistics-Time-Series

ISE. (2020). Photovoltaics Report - Prepared by Fraunhofer Institute for Solar Energy Systems, ISE with support of PSE Projects GmbH (Issue September). www.ise.fraunhofer.de

Jung, B., Park, J., Seo, D., \& Park, N. (2016). Sustainable System for Raw-Metal Recovery from Crystalline Silicon Solar Panels: From Noble-Metal Extraction to Lead Removal. ACS Sustainable Chemistry and Engineering, 4(8), 4079-4083. https://doi.org/10.1021/ acssuschemeng. 6 b00894

Kadro, J. M., \& Hagfeldt, A. (2017). The End-of-Life of Perovskite PV. Joule, 1(1), 29-46. https://doi.org/10.1016/j.joule.2017.07.013

Kasper, A. C. (2011). Characterization and recycling of materials present in cell phone scraps. Caracterização e reciclagem de materiais presentes em sucatas de telefones celulares. UFRGS.

Klugmann-Radziemska, E., \& Ostrowski, P. (2010). Chemical treatment of crystalline silicon solar cells as a method of recovering pure silicon from photovoltaic modules. Renewable Energy, 35(8), 17511759. https://doi.org/10.1016/j.renene.2009.11.031

Klugmann-Radziemska, E., Ostrowski, P., Drabczyk, K., Panek, P., \& Szkodo, M. (2010). Experimental validation of crystalline silicon solar cells recycling by thermal and chemical methods. Solar Energy Materials and Solar Cells, 94(12), 2275-2282. https://doi. org/10.1016/j.solmat.2010.07.025

Koenig, J. L., \& Mannion, J. J. (1966). Infrared study of poly(vinyl fluoride). Journal of Polymer Science Part A-2: Polymer Physics, 4(3), 401-414. https://doi.org/10.1002/pol.1966.160040310

Kuczyńska-Łażewska, A., Klugmann-Radziemska, E., Sobczak, Z., \& Klimczuk, T. (2018). Recovery of silver metallization from damaged silicon cells. Solar Energy Materials and Solar Cells, 176(December 2017), 190-195. https://doi.org/10.1016/j.solmat.2017.12.004

Latunussa, C. E. L., Ardente, F., Blengini, G. A., \& Mancini, L. (2016). Life Cycle Assessment of an innovative recycling process for crystalline silicon photovoltaic panels. Solar Energy Materials and Solar Cells, 156, 101-111. https://doi.org/10.1016/j.solmat.2016.03.020

Latunussa, C., Mancini, L., Blengini, G., Ardente, F., \& Pennington, D. (2016). Analysis of Material Recovery from Silicon Photovoltaic Panels. In EUR 27797 Luxembourg (Luxembourg) Publications Office of the European Union (Issue March). https://doi. org/10.2788/786252

Meszlényi, G., \& Körtvélyessy, G. (1999). Direct determination of vinyl acetate content of ethylene-vinyl acetate copolymers in thick films by infrared spectroscopy. Polymer Testing, 18(7), 551-557. https://doi.org/10.1016/S0142-9418(98)00053-1

Mulvaney, D. (2014). Are green jobs just jobs? Cadmium narratives in the life cycle of Photovoltaics. Geoforum, 54, 178-186. https://doi. org/10.1016/j.geoforum.2014.01.014

Nain, P., \& Kumar, A. (2020). Metal dissolution from end-of-life solar photovoltaics in real landfill leachate versus synthetic solutions: One-year study. Waste Management, 114, 351-361. https://doi. org/10.1016/j.wasman.2020.07.004

Padoan, F. C. S. M., Altimari, P., \& Pagnanelli, F. (2019). Recycling of end of life photovoltaic panels: A chemical prospective on process development. Solar Energy, 177(July 2018), 746-761. https://doi. org/10.1016/j.solener.2018.12.003

Pagnanelli, F., Moscardini, E., Granata, G., Abo Atia, T., Altimari, P., Havlik, T., \& Toro, L. (2017). Physical and chemical treatment of end of life panels: An integrated automatic approach viable for different photovoltaic technologies. Waste Management, 59, 422-431. https://doi.org/10.1016/j.wasman.2016.11.011

Paiano, A. (2015). Photovoltaic waste assessment in Italy. Renewable and Sustainable Energy Reviews, 41, 99-112. https://doi. org/10.1016/j.rser.2014.07.208

Peeters, J. R., Altamirano, D., Dewulf, W., \& Duflou, J. R. (2017). Forecasting the composition of emerging waste streams with sensitivity analysis: A case study for photovoltaic (PV) panels in Flanders. Resources, Conservation and Recycling, 120, 14-26. https://doi. org/10.1016/j.resconrec.2017.01.001

Pinho, J. T., \& Galdino, M. A. (2014). Engineering Manual for Photovoltaic Systems (J. T. (UFPA) Pinho \& M. A. (Cepel) Galdino (eds.); March 2014). Centro de Pesquisas de Energia Elétrica (Cetel) Centro de Referência para Energia Solar e Eólica Sergio de Salvo Brito (Cresesb) - Grupo de trabalho de Energia Solar (GTES). http:// www.cresesb.cepel.br 
Prado, P. F. de A. (2019). Reciclagem de painéis fotovoltaicos e recuperação de metais. [Universidade de São Paulo]. https://doi. org/10.11606/D.3.2019.tde-30012019-141410

Rockaway Recycling. (2019). Metal Prices. Https://Rockawayrecycling. Com/Scrap-Metal- Prices.

Sander, K., Schilling, S., Reinschmidt, J., Wambach, K., Schlenker, S., Müller, A., Jelitte, Springer, J., Fouquet, D., Jelitte, A., Stryi-Hipp, G. \& Chrometzka, T. (2007). Study on the Development of a Take Back and Recovery System for Photovoltaic Products. In Components (Issue 03). Oekopol Gmbh, BMU Project Report (co-financed by EPIA and BSW solar) 03MAP092:

Santos, L. (2009). Avaliação da Eficiência da Separação de Plásticos de Resíduos Sólidos Urbanos por Métodos de Dissolução Selectiva. 1-150.

Scheff, S. W. (2016). One-Way Analysis of Variance. In Fundamental Statistical Principles for the Neurobiologist (pp. 97-133). Elsevier. https://doi.org/10.1016/B978-0-12-804753-8.00006-3

Scheirs, J. (1997). Modern Fluoropolymers: High Performance Polymers for Diverse Applications. Chichester, John Wiley \& Sons.

Shin, J., Park, J., \& Park, N. (2017). A method to recycle silicon wafer from end-of-life photovoltaic module and solar panels by using recycled silicon wafers. Solar Energy Materials and Solar Cells, 162(September 2016), 1-6. https://doi.org/10.1016/j.solmat.2016.12.038

Silver Price. (2019). Silver Price. https://silverprice.org

Silver Price. (2021). Silver price on Feb 26, 2021. https://silverprice.org Soltech. (2016). Personal Communication, ed

Strachala, D., Hylský, J., Vanĕk, J., Fafilek, G., \& Jandová, K. (2017). Methods for recycling photovoltaic modules and their impact on environment and raw material extraction. Acta Montanistica Slovaca, 22(3), 257-269.

Sverdrup, H., Koca, D., \& Ragnarsdottir, K. V. (2014). Investigating the sustainability of the global silver supply, reserves, stocks in society and market price using different approaches. Resources, Conservation and Recycling, 83, 121-140. https://doi.org/10.1016/j. resconrec.2013.12.008
Tammaro, M., Salluzzo, A., Rimauro, J., Schiavo, S., \& Manzo, S. (2016). Experimental investigation to evaluate the potential environmental hazards of photovoltaic panels. Journal of Hazardous Materials, 306, 395-405. https://doi.org/10.1016/j.jhazmat.2015.12.018

Tao, J., \& Yu, S. (2015). Review on feasible recycling pathways and technologies of solar photovoltaic modules. Solar Energy Materials and Solar Cells, 141, 108-124. https://doi.org/10.1016/j.solmat.2015.05.005

Tao, M., Fthenakis, V., Ebin, B., Steenari, B. M., Butler, E., Sinha, P., Corkish, R., Wambach, K., \& Simon, E. S. (2020). Major challenges and opportunities in silicon solar module recycling. Progress in Photovoltaics: Research and Applications, 28(10), 1077-1088. https:// doi.org/10.1002/pip.3316

Wang, T.-Y. Y., Hsiao, J.-C. C., \& Du, C.-H. H. (2012). Recycling of materials from silicon base solar cell module. 2012 38th IEEE Photovoltaic Specialists Conference, 002355-002358. https://doi. org/10.1109/PVSC.2012.6318071

Weckend, S. (IRENA), Wade, A., \& Heath, G. (IEA-P. (2016). End of Life Management Solar PV Panels. www.irena.org

Xu, Y., Li, J., Tan, Q., Peters, A. L., \& Yang, C. (2018). Global status of recycling waste solar panels: A review. Waste Management, 75, 450-458. https://doi.org/10.1016/j.wasman.2018.01.036

Yi, Y. K., Kim, H. S., Tran, T., Hong, S. K., \& Kim, M. J. (2014). Recovering valuable metals from recycled photovoltaic modules. Journal of the Air and Waste Management Association, 64(7), 797-807. https://doi.org/10.1080/10962247.2014.891540

Zerbi, G., \& Cortili, G. (1970). Structure of poly-(vinyl fluoride) from its infrared spectrum. Spectrochimica Acta Part A: Molecular Spectroscopy, 26(3), 733-739. https://doi.org/10.1016/05848539(70)80117-9 